\title{
NEW CHAPTER OF DIPLOMATIC RELATION BETWEEN INDONESIA-AMERICA UNDER NEW CONTRACT OF FREEPORT-MCMORAN
}

\author{
Muhammad Shobaruddin \\ College of Interdisciplinary Studies (CIS), Thammasat University \\ mshobaruddin@gmail.com
}

\begin{abstract}
Abstrak
Freeport-McMoran telah mengeksplorasi sumber daya alam yang berharga di Indonesia dengan menggali emas dan tembaga di Papua sejak 1967. Esai ini menganalisis dampak dari perjanjian baru terhadap masa depan hubungan bilateral AS-Indonesia serta mengungkapkan pendekatan diplomatik Jokowi. Analisis dalam artikel ini menggunakan pendekatan kualitatif berbasis data sekunder. Data dikumpulkan dari laporan resmi Freport-Mcmoran dan sumber lain yang relevan. Pemerintah Indonesia selalu berusaha melobi pemerintah AS melalui diplomasi yang lembut untuk menjaga hubungan bilateral. Renegosiasi memungkinkan perpanjangan kontrak perusahaan (hingga 2041) yang akan berakhir pada 2021. Pemerintah Indonesia masih membutuhkan AS sebagai mitra bilateral karena negara super power ini telah memainkan peran penting dengan memberikan kontribusi pertumbuhan ekonomi, pembangunan demokrasi, dan keamanan nasional. di Indonesia. Oleh karena itu, Indonesia dengan hati-hati mendekati pemerintah AS untuk menghindari dampak negatif dari negosiasi ulang Indonesia-Freeport.
\end{abstract}

KataKunci: Hubungan Diplomatik, Indonesia-Amerika, dan Freeport-Mcmoran.

\begin{abstract}
Freeport-McMoran has explored valuable natural resources in Indonesia by digging gold and copper in Papua since 1967. This essay analyzed the impacts of this new agreement toward the future of the US-Indonesia bilateral relationship as well as reveal Jokowi's diplomatic approach to gain this agreement.The analysis in this article used a qualitative approach based on secondary data. The data collected from the official reports of Freport-Mcmoran and other relevant sources. Indonesian government always tries to lobby US government through soft diplomacy in order to maintain bilateral relationship. The renegotiation allows the contract extension of the company (until 2041) which will be expired in 2021. Indonesian government still needs the US as bilateral partner since this super power country has already played significant roles by contributing economic growth, democratic development, and national security in Indonesia. Hence, Indonesia is carefully approaching the US government to avoid negative effects of Indonesia-Freeport's renegotiation.
\end{abstract}

Keywords: Diplomatic Relation, Indonesia-America, and Freeport-Mcmoran.

Diterima 26 Januari 2018; Diterima dengan revisi 4 April 2018; Dipublikasikan 1 Mei 2018

2406-9515 (p) / 2528-441X (e)

(C) 2018 Muhammad Shobaruddin. Dipublikasikan oleh JIAN FIS UNY 


\section{INTRODUCTION}

Freeport-McMoran has explored valuable natural resources in Indonesia by digging gold and copper in Papua since 1967. Despite they gained a lot of 'natural legacy', they give only $9.36 \%$ of their revenue to Indonesian government. This inequality profit-shared encouraged government to renegotiate his contract with Freeport-McMoran which will be expired in 2021, in order to give appropriate contribution to people, especially indigenous people in Papua. Indonesian government has tried to renegotiate it since Soeharto regime (the second President of Republic of Indonesia) in 1990 which asked the company to divest $10 \%$ of his stock to the government. However, the US diplomatic power which concern to maintain his power and profit sharing on this company made Soeharto government failed to renegotiate it. In contrast, Soeharto precisely gained bribe from Freeport to protect this company. Moreover, this regime did not require Freeport to give contribution to landowner, the Amungme and Komoro people (Leith. 2002). Hence, profit shared inequality still continuous until right now.

In January and February 2017, Indonesian government issued new regulation to address exports of unrefined metals, including copper concentrate and anode slimes, and other matters related to the mining sector. The policy issued due to Jokowi's commitment to prioritize natural resources in Indonesia for national interest. Consequently, Indonesian government withdraw FreeportMcMoran's export license in January 2017. This policy effect to FreeportMcMoran's (PT Freeport Indonesia/ PTFI) export license and operation contract which will be ended in 2021. In 29 august 2017, Freeport CEO, Richard Adkerson (together with Sri Mulyani, Ministry of Finance and Ignatius Jonan, Ministry of Energy and Mineral Resources) announced to the media that his company agree to fulfill the new requirements of regulation from Indonesian government, in order to get contract extension in Papua until 2041. Consequently, PTFI need to divest $51 \%$ stock to Indonesian interest, establishing smelter within 5 years as well as change their contract from Contract of Work (CoW) to special license (IUPK).

This new agreement will bring significant impact of Freeport's contribution to Indonesian government. In contrast, American government will get drawbacks of this negotiation due to its impact on their revenue. Hence, American government will interfere this negotiation 
in order to maintain their benefit from this company. Moreover, Freeport has significant influences in US political realm by giving a lot of political fund for the US politicians.

American political leaders have believed that the national interest has also been served by the foreign expansion of US corporations in manufacturing and services. Foreign direct investment has been considered a major instrument through which the US could maintain its relative position in world markets, and the overseas expansion of multinational corporations has been regarded as a mean to maintain America's dominant world economic position (Gilpin. 1987:242).

It would be interesting to discuss and analyze this issue from International Relation perspective. This essay analyzes the impacts of this new agreement toward the future of the US-Indonesia bilateral relationship as well as reveals Jokowi's diplomatic approach to gain this agreement. The first section of this work will explain about Freeport-McMoran as the giant mining company in the world and its relation with Indonesian government. Furthermore, FreeportMcMoran relation with the US government will be displayed on the second section. In the third section, the writer will describe how President Joko
Widodo (Jokowi) lobbies Donald Trump in order to deal with this new policy as well as maintaining US investment in Indonesia remain stable. Finally, conclusion and writer's core analysis will be provided in the last section.

\section{METHOD}

The analysis in this article used a qualitative approach based on secondary data. The data collected from the official reports of Freport-Mcmoran and other relevant sources.

\section{RESULT AND DISCUSSION \\ Freeport-McMoran (PT Freeport Indonesia)}

Freeport-McMoRan Inc. (FCX) is a leading international mining company with headquarters in Phoenix, Arizona. This mining company has operated mainly to explore copper, gold and molybdenum. FCX is the world's biggest publicly traded copper producer. FCX has three branch companies, the first, the Grasberg minerals district in Indonesia (PT Freeport Indonesia), as one of the world's largest copper and gold deposits. Secondly, Freeport-McMoran Corporation, a significant mining operations in North and South America, including the large-scale Morenci minerals district in Arizona and 
the Cerro Verde operation in Peru and the last is Atlantic Copper in Africa.

Freeport-McMoran has started the activity of mining in West Papua, Indonesia in 1972. This massive mining company recorded as the biggest producer of gold in the world and the second largest producer of copper (Prakash, 2011). This mining company is located along the "ring of fire", a geological area where the IndoAustralian and Pacific plates collide, the Freeport mining concessions are in potentially one of the highest mineralized zones in the world. Referred to in the industry as "an elephant" a geological term for an extremely rich mineral deposit-Grasberg dwarfed Ertsberg in every respect (Leith, 2002). PT Freeport Indonesia highly contributed about $33 \%$ to
Freeport-McMoran, meanwhile another athird contributed from South America and the rest is obtained from North America and Affrica, 26\% and $8 \%$ respectively. According to annual report 2016 which was released by Freeport-McMoran, PT Freeport Indonesia's revenue significantly increased in 2016 compared to 2015 in both copper and gold selling.

\section{Freeport and US Government}

Freeport absolutely needs support from the US government, in order to maintain their branch corporations in some countries, like Indonesia, Africa, and Peru. This company believes that public policies significantly affect their operation, future business, opportunities, employees, shareholders, and the communities in which Freeport operates.

Table 1. Total Revenue of PT Freeport Indonesia in 2016

\begin{tabular}{|c|c|c|c|c|}
\hline No & Item & $\begin{array}{c}\text { Mining Totaled } \\
\text { (pounds) }\end{array}$ & Price per Pound/ounce (US\$) & $\begin{array}{c}\text { Total Price } \\
\text { (USS) }\end{array}$ \\
\hline 1 & Copper & 1.1 Billion & 2.32 & 2.6 Billion \\
\hline 2 & Gold & 1.1 million & 1,237 & 1.3 Billion \\
\hline \multicolumn{3}{|c|}{ TOTAL } & 3.9 Billion \\
\hline
\end{tabular}

Table 2. Total Revenue of PT Freeport Indonesia in 2015

\begin{tabular}{|c|c|c|c|c|}
\hline No & Item & $\begin{array}{c}\text { Mining Totaled } \\
\text { (pounds) }\end{array}$ & Price per Pound/ounce (US\$) & $\begin{array}{c}\text { Total Price } \\
\text { (USS) }\end{array}$ \\
\hline 1 & Copper & 744 million & 2.33 & 1.7 Billion \\
\hline 2 & Gold & 1.2 million & 1,129 & 1.4 Billion \\
\hline \multicolumn{3}{|c|}{ TOTAL } & 3.1 Billion \\
\hline
\end{tabular}


It is inevitably that Freeport-McMoran lobby as well as provides financial support to the US politicians. Based on writer's analysis there are several contributions from Freeport-McMoran to the US government:

1. Political Financial Support

As stated in FreeportMcMoran website, this company has given financial support to both the US house representative and senate candidate from Democrat and Republican Party. In 2016, FCX spent $\$ 108,500$ for Federal Disbursement: $\$ 60,000$ for the US House Candidates and \$48,500 for the US Senate Candidate. Moreover, FCX also gave contribution in Arizona and Colorado. FCX spent totally $\$ 36,150$ to candidates in Arizona, they gave $\$ 21,400$ to Arizona House Candidates, $\$ 12,850$ to Arizona Senate Candidate, and $\$ 1,900$ to Arizona Local Candidate. Furthermore, FCX donated the amount of $\$ 3,400$ to candidates in Colorado, they gave $\$ 1,600$ and $\$ 1,800$ respectively to Colorado House Candidates and Colorado Senate Candidate. In addition, this company also contributed $\$ 1,000$ to the only one New Mexico House Candidate, namely Zimmerman John. The total amount of FCX's political spending in 2016 is $\$ 149,050$. Based on FCX's official website the company always allocates their budget every year for political spending in order to obtain legal support from the US government.

2. Providing Vocation

FCX also provided vocation to American workers in headquarter of this multinational corporation in Arizona. Since 2009, approximately $\quad 30.000$ American are employed by Freeport McMoran. This huge number of American employees inevitably will impact to US

Table 3. Total Disbursement for Political Activity

\begin{tabular}{|c|c|c|c|c|c|c|}
\hline Year & Federal & Arizona & Colorado & $\begin{array}{c}\text { New } \\
\text { Mexico }\end{array}$ & Texas & Total \\
\hline 2016 & $\$ 108,500$ & $\$ 36,150$ & $\$ 3,400$ & $\$ 1,000$ & - & $\$ 149,050$ \\
\hline 2015 & $\$ 104,500$ & $\$ 15,250$ & $\$ 450$ & $\$ 1,000$ & - & $\$ 121,200$ \\
\hline 2014 & $\$ 171,500$ & $\$ 40,450$ & $\$ 4,250$ & $\$ 5,200$ & $\$ 500$ & $\$ 221,900$ \\
\hline 2013 & $\$ 72,600$ & $\$ 29,108$ & - & - & - & $\$ 101,708$ \\
\hline 2012 & $\$ 150,500$ & $\$ 14,896$ & $\$ 5,500$ & $\$ 13,300$ & - & $\$ 184,196$ \\
\hline
\end{tabular}


consideration in determining their foreign policy related to Freeport Branch companies, especially in Indonesia. In addition, unstable situation in PT Freeport Indonesia which contributed $30 \%$ of Freeport McMoran's revenues will influence future prospect of American worker in the headquarter of Freeport Company. By those two things, the writer tends to believe that renegotiation between Indonesian government and FCX will get respond from the US Government. Although Richard Adkerson as President and CEO of FreeportMcMoRan has been agreed with the requirements from Indonesian Government to extend his contract, FCX has significant opportunity to use his political power in the US government to negotiate or influence Indonesian government. Moreover, some FCX stock owner handle important position in the US government such as Carl Icahn as President Donald Trump's Special Advisor who hold 7\% FCX stock and became the majority stockholder in the last 1.5 years. As stated in Detik.com (20/02/2017), Richard stressed that some politician in US government especially those who hold FCX stock put more concern on dynamic situation in Indonesia related with PT Freeport Indonesia. Therefore, Indonesian government should anticipate for the future uncertainty.

\section{Jokowi's Diplomacy}

As a populist leader of democratic country, Jokowi's administration struggles to encourage PTFI give more contribution to the nation. This is because PTFI has already explored Indonesian natural resources (gold and copper) for more than 40 years. Consequently, Jokowi issued export mining regulation and give special license to PTFI. Previously, PTFI operated mining company under Contract of Work (CoW) with Indonesian government, but it will be expired in 2021. Therefore, PTFI need to negotiate with Indonesian government to extend their license in exploring and exporting their mining product. Indonesian Government issued special license namely IUPK, wherein it allow PTFI to operate their company until 2041.

This special license bring significant impact for both sides, PTFI and Indonesian government. As stated by Dadan Kusdiana, A chief of public communication under Ministry of Energy and Mineral Resources (ESDM), unlike with CoW which made company and government has equal position on negotiation. IUPK tend to give prominent 
position to the government, hence government has authority to withdraw operating license of the company. Moreover, PTFI was obligated to establish smelters within five years to process refined product before it is exported. In addition, the most significant impact of this special license is PTFI should divest its stock and allocate $51 \%$ to government or local companies.

The negotiation between PTFI and Indonesian government finalized by conducting Framework of Agreement (FoA) on 27 August 2017 at the office of Ministry of Energy and Mineral Resources in Jakarta. This meeting attended by two ministries which representing Indonesian government, Ignatius Jonan as Ministry of Energy and Mineral Resources and Sri Mulyani as Ministry of Finance, whereas PTFI was represented by Richard Adkerson as President and CEO of Freeport-McMoRan and members of PT-FI's Board.

Responding this FoA as mentioned at Freeport-McMoran News Release on 29 August 2017, Richard Adkerson said:

"We are pleased to announce an agreed framework to support our ongoing operations and investment program in Papua. Reaching this understanding on the structure of a mutual agreement is significant and positive for all stakeholders. Important work remains on documenting this agreement and we are committed to completing the documentation as soon as possible during 2017."

The News Release also mentioned that PTFI's contract under IUPK will be extended until 2041. Moreover, the company also agrees to divest their ownership in PTFI at fair market value so that Indonesia interest own $51 \%$ of PTFI's shares.

In addition, Ignatius Jonan explained that the outcome of this new agreement in accordance with instruction of President Jokowi to prioritize national interest, Papuan prosperity, national sovereignty, and maintain climate investment remains stable. Therefore, the writer argues that Indonesian government prefers to use soft diplomacy in renegotiating this giant company's contract. These endeavors are not only to increase Indonesian benefit, but also maintaining relation between Indonesian government and foreign investor, especially the US investors who play significant role in Indonesia. Moreover, Jokowi has tried to maintain good bilateral relationship with the US, by inviting Donald Trump to visit Indonesia when both leader attending G20 summit on 8 July 2017 in Germany. Jokowi stressed that million of Trump's fans in Indonesia 
eager to see the President of this powerful country.

This $G$ to $G$ negotiation is significantly important due to the US government benefit from FreeportMcMoran that has been explained in point C. However, as developing country Indonesia need to maintain its bilateral relationship with the US which has important roles in term of security, investment, and politic in Indonesia. Since in 2001 US government gave military assistance through several programs such as International Military Education and Training (IMET), Anti-terrorism Assistant Program, Counterterrorism Fellowship Program, Military Spare Part for nonLethal Item, Foreign Military Finance (FMF), and Economic Support Fund (A. Obrien. 2005). Consequently, Jokowi needs to continuous his approach with the US government, but in the same time he needs to keep on eye the progress of renegotiation with PT Freeport Indonesia.

Based on those explanation, writer optimist that this re-negotiation will bring win-win solutions between both side. In the one hand, PTFI can continuous exploring and exporting mining product in Papua for the next 20 years. Meanwhile, Indonesia as the land owner can take benefit of this company and give appropriate contribution to people.
Furthermore, bilateral relations between the US and Indonesian government remain stable.

\section{CONCLUSION}

PT Freeport Indonesia (PTFI) is going to extend their contract which will be expired in 2021. This giant mining company will continue his operation due to a lot of gold and copper reserves under the land of Papua. Meanwhile, Indonesian government has already changed the regulation for exploring raw materials, in order to protect natural resources as well as contribute to human development. Consequently, Indonesian government proposed a new regulation or a new contract to PTFI as the main requirements to extend their operation license. Indonesian government required PTFI to change their contract from CoW to IUPK, divest their stock $51 \%$ to Indonesian government or local company, and establishing smelter within 5 years.

Although PTFI has great dilemma related with this situation, the amount of copper and gold concentrate in Papua lead them to agree with this new regulation. However, this negotiation will be responded by US government. This is because PTFI contributed a lot of financial support toward US government both house representative and senate from 
Democrat and Republic Party. Moreover, some of US influential leaders owning stock of PTFI, such as Carl Icahn as President Donald Trump's Special Advisor who hold 7\% FCX stock and became the majority stock holder in the last 1.5 years. Despite the US government probably will use their power to negotiate or even impose Indonesian government, writer optimist that they will maintain this operating company although under new regulation and agreement. It seems impossible to Freeport finds another nonrenewable natural resources (gold and copper) like in Papua.

Nevertheless, Indonesian government always tries to lobby US government through soft diplomacy in order to maintain bilateral relationship. Indonesian government try to convince the US government that the renegotiation still have mutual benefit for three parties, Indonesian government, US government, and Freeport McMoran. The renegotiation allows the contract extension of the company (until 2041) which will be expired in 2021. Based on this argument, Indonesian government still need the US as bilateral partner since this super power country has already played significant roles by contributing economic growth, democratic development, and national security in Indonesia. Hence, Indonesia is carefully approaching the US government to avoid negative effects of IndonesiaFreeport's renegotiation.

In the last analysis, this case can be analyzed from Liberalism perspective theory due to involvement of non-state actor (Freeport-McMoran/ PT Freeport Indonesia) in this international relation. As non-state actor, Freeport-McMoran involves their home country (US) to deal with their own problem in host country (Indonesia). This MNC has changed bilateral relations realm between Indonesia and America.

\section{REFERENCE}

Dicken, P. (2015). Mapping the Changing Contour of the World Economy. New York The Guilford Group.

Freeport-McMoran. (2016). Annual Report 2016. Arizona, United States.

Freeport-McMoRan. News Release. Freeport-McMoRan Announces Framework for Agreement with Indonesian Government Regarding Long-Term Operating Rights for PT Freeport Indonesia, Arizona. 29 August 2017.

Leith, D. (2002). Freeport and the Suharto Regime 1965-1998. Project Muse. (14/1). P.69-100.

PTFI. (2013). Annual Report (Laporan Tahunan), Community Affairs.

Sethi, S.P. and David B.L. (2011). Freeport-McMoran Copper \& Gold Inc.: An Innovative Voluntary Code of Conduct to Protect Human Right, 
Create Employment Opportunities, and Economic Development of Indigenous People. Journal of Business Ethic. 103:1-30.

\section{Online Sources:}

BBC News. (2017). Pemerintah Indonesia Dapatkan $51 \%$ Saham dan Perpanjang Kontrak Freeport. Retrieved from http://www.bbc.com/indonesia/indo nesia-41079090.

Detik Finance. (2017). Freeport: Staf Khusus Trum Pemegang Saham Terbesar Kami. Retrieved from https://finance.detik.com/energi/342 7109/freeport-staf-khusus-trumppemegang-saham-terbesar-kami.

Freeport-McMoran. (2017). Political Activity and Spending Practices. Retrieved from https://www.fcx.com/sustainability/ approach/policies/political-activityand-spending .

Freeport-McMoran. (2017). Political Activity Documents. Retrieved from https://fcx-

prod.fmi.com/sustainability/approac h/policies/political-activitydocuments.

Obrien, Adam. (2005). The U.S.Indonesian Military Relationship. Retrieved from https://www.cfr.org/backgrounder/u s-indonesian-military-relationship.

Papua Pos. (2014). RAPBD Papua 2015 Capai Rp12,74 Triliun. Retrieved from

http://papuapos.com/index.php/utam a/item/4979-rapbd-papua-2015capai-rp1274-triliun.

PT Freeport Indonesia. (2017). Fakta Freeport Indonesia. Retrieved from https://ptfi.co.id/id/media/facts- about-feeport-indonesia.

Sundaryani, Fedina. (2017). Jokowi Invites Trump to Indonesia. The Jakarta Post. Retrieved from http://www.thejakartapost.com/news /2017/07/09/jokowi-invites-trumpto-indonesia.html

Suwandi, Dhias. (2016). Antara Papua. DPRD sahkan APBD Papua Perubahan 2016 sebesar Rp13,07 triliun. Retrieved from http://www.antarapapua.com/berita/ 457025/dprp-sahkan-apbd-papuaperubahan-2016-sebesar-rp1307triliun.

The Gim Magazine. (2017). Freeport to divest majority stake in Grasberg to Indonesia. Retrieved from http://www.wandtv.com/story/3625 9897/corporate-news-blog-freeportmcmorans-and-indonesiangovernment-agree-to-frameworkfor-agreement-regarding-miningrights-for-indonesian-operations.

Wijayanto, Nanang. (2015). Koran Sindo. Izin Freeport Akan Diperpanjang 20 Tahun. Retrieved from https://ekbis.sindonews.com/read/10 11443/150/izin-freeport-akandiperpanjang-20-tahun-1433992738. 